\title{
Daniel 3 as satirical comedy
}

\begin{abstract}
The tale in Daniel 3 is told to people living in the second century BCE whose lives were threatened by the Syrian Antiochus IV Epiphanes when they disobeyed his command to forsake their religion as a desperate measure of quenching recurrent Jewish rebellion. After reading the tale the Jews could not help but laugh at worldly kings who preposterously cut down the Jewish God, only to find out that he is in charge of the world, and that God has predetermined the destination of their kingdoms. The article describes the humorous and satirical elements in the tale in order to explain its impact on the initial readers. The fantastical elements of surviving a fiery furnace and a mighty king bowing before the god of a people conquered by his power, told tongue in cheek, can only be explained sensibly as satire and comedy.
\end{abstract}

\section{INTRODUCTION}

The Daniel tales (Dan 1-6) had at times been interpreted as haggadic tales, wisdom tales, customized martyr tales, midrash tales, religious or popular romances, miracle tales, court tales, court legends, and comedies, and in each case the interpretation had extracted some elements that are useful in reading and understanding the tales. In this article the narratological approach would be followed where we concentrate on the satirical elements in Daniel 3 in order to endeavour to unlock some of the impact of the tales on readers.

Satire can be defined as the poetic ridiculing of vices or follies of institutions and individuals by way of irony, sarcasm, etcetera with the purpose of changing readers' or listeners' perspective of these institutions or individuals by exposing their vices or follies. Satire is a form of comedy that is the description of a humorous or farcical incident of life representing everyday life and with a happy ending. The premise of the article is that there are enough comical and satirical elements in Daniel 3 in order that a satirical analysis can be useful in explaining the passage.

The tales (Dan 1-6) do not have apocalyptic features but form part of the Book of Daniel where the second part, the visions, are apocalyptic. Apocalyptic texts use mythological and metaphorical language to describe the indescribable of otherworldly realities and the battles that would introduce that reality, a reality that would end the present world and introduce a new world order. The present world for first-time readers of the Book of Daniel was the oppression by a Syrian king, Antiochus IV Epiphanes, and the tales mock and ridicule the Syrian king and his gods by emphasizing the power of the sovereign God of the Jews over all powers.

Two of the six tales contained in the first part of the Book of Daniel (1-6) entails statues. In Daniel 2 a composite statue of extreme brightness is portrayed with a head of fine gold, chests and arms of silver, belly and thighs of bronze, legs of iron, and feet of partly iron, partly clay (vv. 31-33). This statue is struck at its feet of clay and iron by a stone that breaks away, untouched by any hand, and shatters the statue into pieces as fine as chaff on the threshing-floor in the summer. The wind blew these pieces away and not a trace is left behind, while the stone grows into a great mountain that fills the whole earth (vv. 34-35). The meaning of the dream is that the kingdoms of the earth, including that of Nebuchadnezzar, a kingdom of sovereignty, power, strength and honour bestowed by God upon him, will be destroyed in order to accommodate a 
kingdom which will never be destroyed or pass into the hands of another race, lasting forever while it shatters and absorbs all the previous kingdoms (vv. 37, 44).

In Daniel 3, king Nebuchadnezzar builds a statue entirely of gold; as if he wishes to topple the dream he had according to Daniel 2 (Lucas 2002:93). It is as if the king wants to assure that his own kingdom would last forever and that no weaker kingdom following his might threaten the kingdom he established with such power.

\section{INITIAL READERS OF DANIEL 3}

A presupposition used by exegetes is that the biblical text was written for a specific purpose and that the hermeneutical process should respect that purpose. Before analyzing Daniel 3 the question is asked: what were the social and political conditions in which the initial readers probably found themselves? The text can be read in many other ways but for our purposes it is functional to understand these conditions in order to try and hear what initial readers heard. All speech acts, besides saying something (locutionary act), do something in saying (illocutionary act), and finally achieve a certain effect by saying (perlocutionary act) (Ricoeur 1976:14).

Although some scholars are negative about defining the community addressed by the Book of Daniel, maintaining that there is no necessary connection between apocalypses and apocalyptic communities (Grabbe 1989:39), Beyerle (2002:205-206) is of the opinion that "no modern scholar who asks historical questions can ignore the social environment of apocalyptic literature." The sociological approach can be a major tool for the investigation of apocalyptic texts with the purpose of describing the communities it addressed.

Apocalyptic texts use mythological and metaphorical language to describe the indescribable of otherworldly realities and the battles that would introduce that reality but it is possible to deduce the social setting in which it originated. According to form criticism each genre arises in and is appropriate for its use in a particular situation. And the classical distinction made between apocalypse as a literary genre, apocalypticism as a specific religious and social movement, and apocalyptic eschatology as a specific religious perspective allows the description of the circles that composed and transmitted apocalyptic ideas and ideologies as well as the circumstances in which it happened.

None of the apocalyptic movements has survived until the present time and contemporary sociological models are of limited help in describing these movements; therefore the startingpoint of such an investigation should be the text itself, not a theory of a hypothetical movement that may be related to the sources.

The tales in the Book of Daniel is combined with visions with a clear apocalyptic intent and even though it is accepted that the tales were earlier and functioned at first in another context (Collins 2004:554), it must be taken into account that it now forms part of an apocalyptic book. If the text is taken as the starting-point, then the two different genres, court-tales and visions, go back to different Sitze im Leben or social settings. The court-tales reflect the fate of Jews during the Babylonian exile and in the diaspora, while the visions are addressed to pious Jews persecuted for their faithfulness to their God and his law. The court-tales are reutilized to form the first part of a book containing also visions with apocalyptic intent. The Daniel apocalypse answers to this crisis. What are the belief-system and social-system of the two different social contexts in which the court-tales functioned?

During the sixth century BCE, Judah was disempowered by its exile to Babylon when its monarchy, religious and economic system were disbanded. A foreign king became all-powerful with the exiles existing without any legal rights. In the second century BCE, when the court-tales were retold, the Syrian king disempowered pious Jews when he suspended the temple cult and 
prohibited religious customs like circumcision and even possession of Jewish scriptures. Again the foreign king became all-powerful when he prosecuted transgressing Jews.

The Book of Daniel refers to maśkilîm, the wise men (Dan. 11:33-35; 12:3, 10; cf. 1 Macc. 2:42; 7:12-13; 2 Macc. 14:6) that will cause many to understand when there is oppression by evil power (Dan. 11:33). Recent scholarship does not allow identification of this group with an apocalyptic movement or a community. However, the maśkilîm fit with a highly educated intellectual elite group, scribes that utilize motifs and forms that originated from earlier prophetic texts but reworked it as written apocalypticism. In this way the Book of Daniel becomes a transition from earlier prophetic traditions in the Hebrew Bible to the productive apocalyptists from the Second Temple period (Brueggemann 1997:172). The social milieu of the Daniel apocalypse can be described in terms of a well-educated, upper-class group, and not oppressed and deprived outsiders (cf. Josephus' Antiquities 10 §266; Birch et al 1999:445).

The Daniel apocalypse's hope for an otherworldly reality forms the centre of the maśkilîm's belief-system as a result of the crisis presented to Jewish religion by the Hellenization of the Jerusalem Temple by Antiochus IV Epiphanes. The Maccabean revolt reflects a struggle within the Jewish community (Bickerman 1984:1-40) between Hellenizing Jews supporting Antiochus' Hellenization policy and a (minority) group of Jews protecting their tradition. The maśkîlîm used the Torah but also privileged revelations to the "wise" to create the apocalyptic worldview of the Book of Daniel (Collins 1985:140). The themes determining the context of the readers of the Book of Daniel are the oppression by a foreign king of Jews' religious heritage and the implications for the sovereignty of the Jewish God.

Barr (1984:42) emphasizes that ancient Jewish apocalypses use symbols as a means of indicating a symbolic transformation of the world, empowering its adherents to dream of a reality stripped of the negative elements caused by the crisis preceding and causing the apocalypse. On the one side is the reality of a lost and corrupt world and on the other side is the reality of salvation for believers with everlasting consequences (Beyerle 2002:224). While Antiochus' persecutions threatened Jewish identity there was a heavenly world closely related to future hope with the identification of the persecuted, the maśkiliim, with heavenly beings in Daniel 12:1-3 (cf. 1 En. 104:2-6), making the symbols concrete. These apocalyptic symbols were derived from older traditions but rearranged in a way that it became disconnected from the symbolic universe of everyday experience. It is this new understanding of rearranged symbols that constitute the new reality of the Daniel apocalypse.

\section{ANALYSIS OF DANIEL 3}

\begin{tabular}{|l|l|}
\hline a Nebuchadnezzar had a golden statue made & v. 1 \\
\hline b he summoned all to attend the dedication of the statue & v. \\
\hline c everybody attended the ceremony & v.3 \\
\hline d a herald ordered all to fall down and worship the statue at the sign & v. 4-5 \\
\hline c the herald announces that failure to worship would be answered with death & v. 6 \\
\hline b everybody worshipped the statue at the given sign & v. 7 \\
\hline
\end{tabular}

The first part of the tale develops sequentially without any sign of tension. Then the tone changes in the second part.

\begin{tabular}{|l|l|}
\hline e some accused the three Jews of disobedience to the order & $\mathrm{vv} .8-12$ \\
\hline f Nebuchadnezzar interviews the three Jews & $\mathrm{vv} .13-15$ \\
\hline g the three Jews answered to the accusation & $\mathrm{vv} .16-18$ \\
\hline f the king ordered the death sentence for the insubordinate Jews & $\mathrm{vv} .19-20$ \\
\hline e the king's order is executed & $\mathrm{vv} .21-23$ \\
\hline
\end{tabular}


This part of the narrative is circular with the accusation made by "some Chaldeans" ${ }^{1}$ against the three Jewish courtiers (e) who won the battle for knowledge and skill in every aspect of literature and learning, with Daniel also having the gift of interpreting every kind of vision and dream (Dan. 1:17), and making enemies as implied by Dan. 3:8. The king interviews the accused (f), listen to their defence (g), and orders the death sentence on them (f), which is executed (e).

The next part contains two songs in the deutero-canonical literature, representing poems of praise to Israel's God. Most researchers allow that these passages are from an Aramaic original, even though it is only preserved in the Greek and Syriac versions. ${ }^{2}$ In MT's Aramaic text v. 24 corresponds to the Greek v. 91. These songs suppose that Azariah acts as the leader in the absence of Daniel, the most gifted of the four Jewish courtiers.

song of Azariah in the furnace song of the three young men

vV. 24-50 vv. $51-90$

The last part contains the dénouement of the plot created by the order to throw the three insubordinate Jews into a furnace which was made seven times hotter than usual and led to the instant death of the men who threw them into the furnace (vv. 20, 23).

\begin{tabular}{|l|l|}
\hline h the king is surprised by the presence of a fourth man in the furnace & $v v .51-90$ \\
\hline ihe calls the three men from the furnace & $v .26$ \\
\hline everybody sees that they have not been harmed in the furnace & $\mathrm{v} .27$ \\
\hline k the king acknowledges the power of the Jews' God & $\mathrm{v} .28$ \\
\hline k he orders all to show respect to the Jews' God & $\mathrm{v} .29$ \\
\hline $\mathrm{k}$ he favours the three Jews & $\mathrm{v} .30$ \\
\hline
\end{tabular}

The tale is constructed in a straightforward way to build up to the climax in vv. 28-30 where the sovereignty and power of the Jewish God is emphasized. The songs in the deuterocanonical books have the same purpose, with phrases such as, "you are upright in all that you have done for us, all your deeds are true, all your ways right..." (v. 27); "May you be blessed, Lord, God of our ancestors, be praised and extolled for ever" (v. 52); and "he has rescued us from the Underworld, he has saved us from the hand of Death, he has snatched us from the burning fiery furnace, he has drawn us from the heart of the flame! Give thanks to the Lord, for he is good, for his love is everlasting" (v. 88-89). ${ }^{3}$

The macrostructure can be summarized (Lucas 2002:86):

\begin{tabular}{|c|l|c|}
\hline$A$ & Nebuchadnezzar decrees that a golden image be erected & $1-7$ \\
\hline$B$ & The Jews accused & $8-12$ \\
\hline$C$ & The Jews threatened & $13-15$ \\
\hline$D$ & The Jews confess their faith & $16-18$ \\
\hline$C^{1}$ & The Jews punished & $19-23$ \\
\hline$B^{1}$ & The Jews vindicated & $24-27$ \\
\hline$A^{1}$ & Nebuchadnezzar decrees that the Jewish God be honoured & $28-30$ \\
\hline
\end{tabular}

\section{DANIEL 3 AS SATIRICAL COMEDY}

Satire refers to an unsatisfactory state of affairs, a militant word art where author as well as reader protests against this state of affairs, a reality that is experienced as threatening (Pretorius, 1992:464). In the case of the author and readers of the Book of Daniel it was dangerous to criticize Antiochus IV Epiphanes, and therefore satirical tales that originated in another context

1 "Chaldeans" refer not to the Babylonians in general but to divinatory specialists at the Babylonian court

(Hartman \& DiLella 1978:161; Collins 1993:186; Kirkpatrick 2005:101).

2 Wansbrough 1985:1473; Wills 1990:134-138.

3 The translation in the Jerusalem Bible is used. 
are reutilized to describe the Jew's experience of the situation, but also to empower the Jew to act (Collins 1993:181). The real appeal of satire is in its literary merit; not what is said but how it is said, and what is not said determines the appeal of satire on the reader and listener (Pretorius, 1992:465).

An important element in satire is humour or comedy (Good, 1985:47-56). Humour is difficult to define because it is determined culturally and historically even though humour functions as an anthropological constant (Berger, 1997:10). Humour can be described in terms of three theories, according to Feinberg (1971:3-15): It is aimed at alleviating emotional stress or inhibitions about forbidden or taboo subjects; it is aimed at alleviating incongruity or frustration of expectations when acceptable conceptual patterns are shattered or upset; and it is aimed at confirming feelings of superiority or degradation. Martin (1998:15-60) proposes a holistic, threedimensional model that acknowledges and described the cognitive, emotional and motivational causes of humour.

The storyteller in Daniel 3 playfully uses comedic and satiric elements to entertain the readers while also communicating a message of hope (Gunn \& Fewell 1993:175; Lucas 2002:88). The essence of the tale is the confirmation of the sovereignty of the Jews' God by making fun at the foreign king who sings a song of praise to the Jewish God. Ironies, wordplays, mockery, hyperbole, and the fantastic characterize this short story leading to a highly structured, rhetorical masterpiece that accentuates both the king's grandiose view of himself and his true powerlessness (Valeta, 2008:79).

The king orders a top heavy, towering and tottering golden statue to be built that represents his majesty and power. ${ }^{4}$ The word 3 בל , is a Leitwort and it occurs thirteen times in the chapter (vv. 2, 3, 5, 7, 12, 14, 18); it serves as a code for the Babylonian king's power (Aalders s.a.:79). The dimensions of the golden statue are excessive and exaggerated to the point of being unrealistically awkward (Hartman \& DiLella 1978:160-161; Towner 1984:49; Collins 1993:181; Kirkpatrick 2005:101). The statue is in the form of an obelisk, with a base of three meters across and thirty meters high, causing the figure to be oddly shaped (Collins 1993:181) because it does not conform to the normal proportions of the human body (its proportions is 10:1 in contrast to the body's 6:1 or 5:1; Montgomery 1927:196; Aalders s.a.:78). The dimensions given reflect the Babylonian sexagesimal system, rather than the Egyptian decimal system, of numbers (Lucas 2002:88).

The emphasis in the tale is that Nebuchadnezzar is personally responsible for erecting the statue, and he is orchestrating the whole process, including its inception and unveiling (Kirkpatrick 2005:101). He has a direct interest in the destiny of the statue. That the statue is of gold reveals the economic power of the greatest sovereign on earth and its size reveals this king's permanence and stature (Fewell 1991:39)..$^{5}$ The reader who has first-hand experience of the heavy burden of taxation imposed by the foreign king on his subjects, especially his exilic subjects, sees the irony of the servitude and phenomenal costs needed to build the statue in order to flatter the king's ego and the wasteful extravagance of imperial domination (SmithChristopher 1996:61). The reader probably would have understood that the statue couldn't be

4 The text does not indicate when the erection of the statue happens, as in 2:1, although two Greek translations, the Septuagint and Theodotion, as well as the Syrian translation mention that it happens in the eighteenth year of the reign of Nebuchadnezzar, creating the impression that the king's rule has been well established. There is no good ground to accept the translations' dating of the event (Aalders s.a.:77; Lucas 2002:83).

5 Such statues were known from these times; Herodotus mentions a golden statue of Bel in Babel that was twelve cubits (el) or six meters high, and Diodorus Siculus mentions a statue that is twelve and a half meters high, while the colossus of Rhodes, one of the seven wonders of the world, was seventy cubits or thirty five meters high (Aalders s.a.:78; Lucas 2002:88). 
of solid gold; it would have to be hollow to be in realistic capital terms. The grotesque, immense, disproportionate, golden statue is absurd and initial readers, informed by their faith in the Lord of the universe, might have reacted by smiling at the king's folly (Gunn \& Fewell 1993:174-188).

Anyone reading the Book of Daniel would also see the connection between a statue in Daniel 2 with a head made of gold and the one in this tale (Fewell 1991:38-39). In Daniel 2 Nebuchadnezzar dreams how his empire would eventually topple, and directly afterwards (in terms of narrative chronology) he builds a statue representing his empire signifying its greatness but also its permanence. It is as though the king argues that if he could build a statue that would remain forever, his successors would not be able to topple his empire and in this way he would neutralize the power of the Hebrew God that demonstrated his power to establish his own kingdom at the cost of all earthly kingdoms. The Jewish reader in the second century BCE would know better, however. He would understand that this statue of gold would also be subservient to the sovereign Ruler of heaven and earth. The statue would become a monument to the king's fatal flaw in thinking that he could determine future events relating to his heritage.

The comedic intent of the tale is demonstrated by the use of lists throughout (Coxon 1986:109). There are lists of government officials with grandiloquent and pompous titles in verses 2, 3 and 27; of musical instruments in 5, 7, 10 and 15; and of subjects of the king in 4, 7, and $29 .{ }^{6}$ The repetition in the lists and of the different lists are a technique of wordplay that fixes the reader's attention on the ludicrousness of what is happening (Gunn \& Fewell 1993:175). The king is demonstrating his majestic splendour at all costs - everyone must attend the unveiling of his statue, all kinds of musical instruments must be used, and all people must obey his command to fall down and pay obeisance to the statue. The reader listening for the first time to the tale would feel the pompousness and stiltedness associated with the king's orders.

The lists in staccato form demonstrate the mechanical way in which everything is done in accordance with the wishes of the king and how everyone obeys him, in stark contrast to the three Jews, which the reader meets in verse 12. Perhaps the lists also serve as a satire on pagan culture (Avalos 1991:581).

That the list of all the officials that Nebuchadnezzar summons, including "and all the officials of the provinces" to include those not mentioned under the first six descriptions (v. 3 ), is repeated in identical form in verse 4 for all that come for the dedication of the statue, that turned into worship of the statue, reveals that the author is not interested in merely mentioning facts. The author wants to emphasize that the mighty king orchestrates the erection and dedication of his statue but that he also gets what he wants (Baldwin 1978:102). The audience provides adequate recognition of Nebuchadnezzar's need for social acknowledgement, and the hierarchical pecking order of the kingdom's elite, those who have high status and great honour themselves, affirming the loyal clientage of his administration, need to complete the picture at the ostentatious and pretentious ceremony (Kirkpatrick 2005:102). The size of the statue correlates with the obedience of his subjects, including employees of the treasury, judiciary, advisory, and governing bodies.

The king commands everyone to fall down and worship the statue; a command repeated in identical form in verses $6,7,10,11,12,14,15$ and $18 .^{7}$ And everyone obeys him, as the list

6 By using the same terms for the king's subjects in 4:1 as in 3:29 the tales in Dan. 3 and 4 are linked to each other.

7 The honor demanded by the king for his statue representing his majesty can be defined as "the value of a person in his own eyes, but also in the eyes of society. It is his estimation of his own worth, his claim to pride, but it is also the acknowledgement of that claim, his excellence recognized by society, his right to pride" (Pitt-Rivers 1977:1). Nebuchadnezzar sets up the statue, seeking public acknowledgement, but also arranges for an audience to provide adequate recognition. 
of people, nations, and tongues repeated in verses 4, 7, and 29 (and 31 with slight variation) declares. The musical instruments conscripted for the occasion are mentioned with minor differences in verses $5,7,10$, and 15 . Although the exact nature of the instruments mentioned is not known today the intention is clear, as the author provides all these detail in order to describe the total obedience of everyone to the command of the king (Hartman \& DiLella 1978:154-155; Collins 1993:182; Baldwin 1978:103 reads v. 7 literally, "As soon as they were hearing they were falling down," to demonstrate the total and immediate response of the subjects). The narrative with its repetitions provides the reader with the idea that the king controls everything and everyone obeys the king unconditionally (Bar-Efrat 1984:212).

The penalty for disobedience is mentioned in verses $6,11,15$, and 20 , and the references to a red-hot furnace is repeated in verses 17, 21, 23, and 26 (Baldwin 1978:102 reminds that the adjectives, "burning fiery," appear redundant and is used by way of expressing the superlative). The furnace is heated to extraordinary temperatures according to verses 19 and 22, and "fire" is repeated in verses $24,25,26$ and two times in 27 , making the furnace of fire another Leitmotiv alongside the statue.

Wordplay can be found in the lists of officials in verses 2 and 3 with consonance, a technique of repetition of consonants at the end of words with a rhyming effect. Paronomasia, synonymic assonance and alliteration can be found in verse 4 and consonance is also utilized, again by the definite article ending. Verse 7 closes with paronomasia ("all;" "sound;" "all"), reinforcing the king's expectation of absolute obedience to his commands (Bar-Efrat 1984:201-202). Royal power is absolute, the subjects' obedience is unconditional, and everyone obeys the king (Gunn \& Fewell 1993:175). The highly structured nature of the narrative creates a contrast with the three Jews' behaviour when they persistently refuse to obey the king's orders (vv. 16-18).

In verse 8 a discordant note sounds when the king's advisors denounce their fellow courtiers and their way of reporting agrees with the way the king's command and the lists are described. Verse 9's "O King, live forever!" is repeated in 2:4; 5:10; 6:6 and 21, becoming more and more ironical (Bar-Efrat 1984:67). The Chaldeans repeat the order to fall down and the penalty for refusing, as though the king needs reminding. The names of the three recalcitrant Jews are repeated no less than thirteen times to highlight the comedic aspect (Avalos 1991:587). Readers hear professional jealousy, envy ${ }^{8}$ and xenophobia in the light of the performance of the Jewish component of Babylonian courtiers $(1: 20 ; 2: 46)$ by men who are well aware of the circumstances in which these Jews were appointed and they resent the king's promotion of foreigners over their heads (Baldwin 1978:103-104; Collins 1993:186; Le Roux 1995:29; Lucas 2002:94). They "eat the pieces of flesh torn off from somebody's body" by slandering the Jews (Koehler \& Baumgartner 1958:1121; Baldwin 1978:103; Kutsch 1997:636).

The three Jews are introduced by using their Babylonian names that probably refer to the names of Babylonian gods. The narrator uses it satirically to remind the readers of the interplay behind the tale of the Jewish God and the Babylonian gods, as the friends refer to in verse 18 (Baldwin 1978:104; Le Roux 1995:4; Aalders s.a.:83).

Their reply in verse $16 \mathrm{~b}$, "We do not need to answer you," is not the language of arrogance but only a way to explain that they do not need to manage their own defence (Helberg 1994:47; Aalders s.a.:84), as verse 17 explains, "We have the God we serve and He has the power to save us from your power. And even if he does not save us, you must know that we will not serve your god or worship the golden statue that you erected". Their answer demonstrates that the battle lines are drawn between the different gods rather than between the king and his recalcitrant

8 Kirkpatrick (2005:95) discusses "envy" from an anthropological perspective and defines it as aggression in response to the success of others. "Jealousy" also operates in response to one's own success and seeks to protect one's own possessions, whether of material or social value (Kirkpatrick 2005:96). 
foreign subjects. The Jews face a choice between offering loyalty to a foreign king as patron and maintaining loyalty to their Judean Patron-God (Kirkpatrick 2005:103).

The king's reaction witnesses of his lack of control contra the picture of him created in the first part of the tale. After granting the Jews another opportunity to display their obedience and loyalty he becomes infuriated and his expression (צלמי) was changed (v. 19). The same word is used as for the statue, indicating the identity between the king and his statue. Perhaps the statue is an actual image of the king (Meadowcroft 1995:148), as suggested by verses 12 and 14 (Lucas 2002:88), and the reader remembers how the statue (צלמי) in Daniel was destroyed, satirizing the king (Fewell 1991:51). The Book of Daniel consistently describes the kings' responses in these terms; the kings lack emotional control or maturity and they react in a distorted way to events in contrast to the calm and measured way of reacting of the Jewish protagonists.

The Jews' response is short and measured in contrast to the long windedness and verbosity of the rest of the tale. They simply refuse to serve the king's god and worship his statue even if they die at the king's hand. ${ }^{9}$

The king's reaction is dominated by the references to the fiery furnace, with the fire symbolizing the king's fury and rage (Brensinger 2002:12). The furnace is red-hot (vv. 20, 21, 23, 26) but the fire does not consume the Jews (vv. 24, 25, 26, 27). The clothing of the three Jews is described in an alliterative list while the bounding of them is described in verses 20, 21, 23 and 24, in contrast to their being unbound (v. 25), indicating that the king's will is not done even though he tries his very best (Le Roux 1995:30). The scene creates an atmosphere of absurdity and humour.

That the furnace is heated seven times hotter than normal is hyperbolic and the consumption of the soldiers who throw the Jews into the furnace is grotesque. The seven-fold increase in the heat symbolically participates in the king's enkindled rage and consuming indignation (Kirkpatrick 2005:103). These soldiers bowed before the king's gods and his statue but have to die in carrying out their king's orders, an ironic twist to the tale.

The three Jews are unharmed but also unbound in the fire and walking around with a fourth person whose appearance the king describes as that of a son of the gods. Aalders (s.a.:85) interprets "son of the gods" in terms of ancient belief in creatures belonging for one half to the gods and the other half to humanity, and mentioned that the belief was widespread in the ancient world. He is not correct; for the polytheist Nebuchadnezzar the phrase would rather mean "a member of the pantheon" (Lucas 2002:92). The three Jews in distress find the time to compose and sing two elaborate hymns, as mentioned in the deuterocanonical Greek translation of the Hebrew Bible. ${ }^{10}$ What should have been an execution leads to a theophany and when Nebuchadnezzar approaches the furnace to call the Jews the fire does not consume him as happened to his soldiers (v. 26). He calls the Jews "servants of God Most High," a title for God found in the Psalms, but elsewhere only on the lips of non-Jews (Gn. 14:18; Nb. 24:16; Is. 14:14; Wansbrough 1985:1477).

With the three Jews coming unharmed out of the furnace the author gives a last but abbreviated list of officials present at the ceremony (v. 27a), as though their importance is cut back to size. The officials inspect the three's bodies and hair, clothes and smell (v. 27b). It is as

9 Kirkpatrick (2005:104) explains that in the ancient world religion was bound up in kinship (domestic religion) and politics (political religion) and was thus inseparable from ethnic identity, traditional heritage, and collective honor. Religion concerns the proper respect and homage due to those on the ladder on whose rungs stand those who control one's existence (in terms of Malina's image).

10 Qumran showed conclusively that these additions were not part of the original where 1QDan ${ }^{\mathrm{b}}$, and apparently 4QDand, and other fragments lack the Prayer of Azariah and the Song of the Three Hebrews, like the MT (Lucas 2002:85). 
though they have to make absolutely certain that the men are unharmed, a humorous picture as if the officials are examining the Jews for lice (Valeta 2008:86).

The king has become converted and he utters the believer's prayer in verse 28, praising the Jews' God who rescued his servants when they chose to disobey the king and preferred to die rather than worship the king's gods and statue. Then the king issues another decree declaring that anybody who speaks disrespectfully of the Jews' God would be torn limb from limb and their houses destroyed (v. 29), as radical as the punishment for anyone who refused to bow before the statue. The tale ends with the king promoting the three Jews and showering favours on them (v. 30).

The king's reaction to God's interference reminds of his response in Daniel 2, where he offered an oblation and sacrifice to Daniel, gave him many presents and promoted him to a high rank (2:48-49). Now he embraces the Jews' God, the God of his conquered subjects who was also conquered by the Babylonian king (Good 1984:52). The conversion of the king is however conditional, as verse 29 testifies that his ethics has not changed much when he promises to kill anybody who does not obey his command (Fewell 1991:58; Valeta 2008:86).

Daniel and his friends were already promoted to the top positions according to 2:49; the king cannot give them more power that they have. The king is portrayed as a laughable and preposterous model of instability that reacts emotionally and unrealistically to whatever happens. The narrator is telling the tale with tongue in the cheek and a smile on the face.

The tale is about possessors of true power, with the mighty Babylonian king demonstrating his by erecting a statue of immense proportions just to find (again) that the Jews' God is more powerful and in control of heathen kings and their folly. "The mocking tone of the passage recalls the more obvious jibes of the prophets of the exile who, with devastating sarcasm, denounces the idols of his day as nothing and less than nothing before the greatness of the majesty of the living God whom Israel worshipped and served" (Russell 1989:59). The attack on idolatry witnesses to the real danger that Babylonian idolatry poses to Jewish exiles living in a foreign society and the temptation to bow the knee before the oppressor's mighty gods (Lucas 2002:93).

The heart of the conflict in the tale contains a comparison between the Judean God and the Babylonian king who puts himself in the place that rightly belongs only to God (Kirkpatrick 2005:93).

What initial readers would have heard is that heathen kings are not as all-powerful as they (and their subjects) think, but that they are subject to the authority of the Jews' God. The tale is humorous in order to demonstrate the foolishness of a heathen king in thinking that he can decide about the fate of God's people, the Jews. They would laugh at the Babylonian king who never learns his lesson because the next tale finds the king driven from society and living with the wild animals as a lunatic because he did not confess the rule of the Most High over human sovereignty (4:22). And by laughing at powerful heathen kings they would be encouraged to persist in their faithfulness to God in the face of Antiochus' prohibition to serve him.

\section{SYNTHESIS}

The Daniel tales (Dan 1-6) had at times been interpreted as haggadic tales, wisdom tales, customized martyr tales, midrash tales, religious or popular romances, miracle tales, court tales, court legends, and comedies, and in each case the interpretation had extracted some elements that are useful in reading and understanding the tales. In the article a narratological approach was utilized by concentrating on the satirical elements in Daniel 3 in order to test the premise that there are enough satirical elements in Daniel 3 so that a satirical analysis can be useful in explaining the passage and unlocking some of the impact of the tales on readers. 
Satire is a word art where the author protests against an unsatisfactory state of affairs and a threatening reality (Pretorius, 1992:464). As it was dangerous to criticize Antiochus IV Epiphanes during his oppression of the Jewish religion and identity, satirical tales that originated in another context were reutilized to describe the Jew's experience of the situation, but also to empower the Jew to act. Readers living in the second century BCE who experienced the oppression of a foreign king suppressing their religion could not help but smile when reading the tale in Daniel 3 because the narrator uses satirical humour to demonstrate how worldly kings preposterously cut down the Jewish God, only to find out that he cuts them off because he is in charge of the world, including their kingdoms. The conclusion is that a satirical reading of Daniel 3 provides information about the initial readers' response to the tale because it explains the humorous elements as a way to convey the author's encouragement to his/her listeners.

The tales combine with the visions to form an apocalyptic book that uses mythological and metaphorical language to describe otherworldly realities and the battles between them that determine the present reality and its end when a new world order would introduce the kingdom of Jews as dominating all the kingdoms of the world. The tales mock the Syrian king and his gods when it emphasizes the power of the sovereign God of the Jews over all powers.

\section{BIBLIOGRAPHY}

Aalders, G.Ch. s.a. Daniël. Korte verklaring van de Heilige Schrift. Kampen: Uitgeversmij Kok.

Avalos, H.I. 1991. The Comedic Function of the Enumerations of Officials and Instruments in Daniel 3. CBQ 53:580-588.

Baldwin, J.G. 1978. Daniel. Tyndale Old Testament Commentaries. Leicester: Inter-Varsity.

Bar-Efrat, S 1984. Narrative Art in the Bible. JSOTSup 70. Sheffield: Sheffield Academic.

Barr, D.L. 1984. The Apocalypse as a Symbolic Transformation of the World: A Literary Analysis. Int 38:3940.

Berger, P. 1997. Redeeming Laughter: The Comic Dimension of Human Experience. New York: W. de Gruyter. Beyerle, S. 2002. The Book of Daniel and its Social Setting, in Collins, J.J. \& Flint, P.W. (eds.) The Book of

Daniel. Composition and Reception. Vol 1, 205-228. Boston / Leiden: Brill.

Bickerman, E.J. 1984. Four Strange Books of the Bible: Jonah, Daniel, Koheleth, Esther. New York: Schocken. Birch, B.C., Brueggemann, W., Fretheim, T.E. \& Petersen, D.L. 1999. A Theological Introduction to the Old

Testament. Nashville: Abingdon.

Brensinger, T.L. 2002. Compliance, Dissonance, and Amazement in Daniel 3. EJ 20:7-19.

Brueggemann, W. 1997. Theology of the Old Testament. Testimony, Dispute, Advocacy. Minneapolis:

Fortress.

Collins, J.J. 1985. Daniel and His Social World. Int 39:131-143.

Collins, J.J. 1993. Daniel. A Commentary on the Book of Daniel. Hermeneia. Minneapolis: Fortress.

Collins, J.J. 2004. Introduction to the Hebrew Bible. Minneapolis: Fortress.

Coxon, P.W. 1986. The "List" Genre and Narrative Style in the Court Tales of Daniel. JSOT 35:95-121.

Feinberg, L. (ed.). 1971. Asian Laughter: An Anthology of Oriental Satire and Humor. New York: Weatherhill. Fewell, D.N. 1991. Circle of Sovereignty. Plotting Politics in the Book of Daniel. Second edition. Nashville: Abingdon.

Good, E.M. 1985. Apocalypse as comedy: The book of Daniel. Semeia 32:41-70.

Grabbe, L. 1989. The Social Setting of Early Jewish Apocalypticism. JSP 4:27-47.

Gunn, D.M. \& Fewell, D.N. 1993. Narrative in the Hebrew Bible. Oxford Bible Series. New York: Oxford University.

Hartman, L.F. \& DiLella, A.A. 1978. The Book of Daniel. AB. Garden City, NY: Doubleday.

Helberg, J.L. 1994. Die Boek Daniël. Skrifuitleg vir Bybelstudent en gemeente. Kaapstad: N.G. Kerk-

Uitgewers.

KoehlerL. \& Baumgartner, W. 1958. Lexicon in Veteris Testamenti Libros. Leiden: E.J. Brill.

Kirkpatrick, S. 2005. Competing for Honor. A Social-scientific Reading of Daniel 1-6. Leiden / Boston: Brill.

Kutsch, E. 1997. krt to cut off, in Jenni, E. \& Westermann, C. Theological Lexicon of the Old Testament. Vol 
2. Tr. by M.E. Biddle, 635-637. Peabody, Ma.: Hendrickson.

Le Roux, C. 1995. Profeet en politiek. Daniël. Die Woord vir die mense. Halfway House: Orion.

Lucas, E.C. 2002. Daniel. Apollos Old Testament Commentary 20. Leicester: Apollos. Downers Grove: InterVarsity.

Martin, R.A. 1998. Approaches to the Sense of Humor: A Historical Review, in Ruch, W. (ed.). The Sense of Humor. Explorations of Personality Characteristic, 15-60. New York: W. de Gruyter.

Meadowcroft, T.J. 1995. Aramaic Daniel and Greek Daniel. A Literary Comparison. JSOTSup 162. Sheffield: Sheffield Academic.

Montgomery, J.A. 1927. A Critical and Exegetical Commentary on the Book of Daniel. New York: Charles Scribner's Sons.

Pitt-Rivers, J. 1977. The Fate of Shechem, or the Politics of Sex. Essays in the Anthropology of the Mediterranean. Cambridge: Cambridge University.

Pretorius, R. 1992. Satire, in Cloete, T.T. (red.). Literêre terme en teorieë, 464-465. Pretoria: HAUM Literêr. Ricoeur, O. 1976. Interpretation theory. Discourse and the surplus of meaning. Fort Worth: Texas University. Russell, D.S. 1989. Daniel. An Active Volcano. Edinburgh: Saint Andrew.

Smith-Christopher, D.L. 1996. Daniel, in Keck, L.E. (ed.) The Interpreter's Bible. Nashville: Abingdon.

Towner, W.S. 1984. Daniel. IBC. Atlanta: John Knox.

Valeta, D.M. 2008. Lions and Ovens and Visions. A Satirical Reading of Daniel 1-6. Hebrew Bible Monographs, 12. Sheffield: Sheffield Phoenix.

Wansbrough, H. (ed.) 1985. The New Jerusalem Bible. Standard edition. London: Darton, Longman \& Todd. Wills, L.M. 1990. The Jews in the Court of the Foreign King. Ancient Jewish Court Legends. HDR 26. Minneapolis: Fortress.

\section{KEY WORDS}

Satire

Comedy

Apocalypse

Antiochan oppression

statue of gold

\section{TREFWOORDE}

Satire

Komedie

Apokalips

Antiocheense verdrukking

beeld van goud

Marius Nel

Extraordinary Professor, School of Biblical Studies and Ancient Languages, North-West University,

Potchefstroom

P.O. Box 12373 BENDOR PARK ZA-0713

Cell: +27 83 454-9126 Office: +27 15 295-4508

E-mail: marius@tabernadei.co.za; nel.marius1@gmail.com 